\title{
Retrospective analysis of a case series of patients with traumatic injuries to the craniocervical junction
}

\author{
Análise retrospectiva de série de casos com lesões traumáticas \\ da junção craniocervical
}

\author{
Luiz Adriano Esteves ${ }^{1,2}$, Andrei Fernandes Joaquim ${ }^{1}$, Helder Tedeschi ${ }^{1}$
}

\begin{abstract}
Objective: To evaluate the correlation between the treatment, the characteristics of the lesions and the clinical outcome of patients with traumatic injuries to the craniocervical junction. Methods: This was a retrospective study of patients treated conservatively or surgically between 2010 and 2013 with complete data sets. Results: We analyzed 37 patients, $73 \%$ were men with mean age of 41.7 years. Of these, $32 \%$ were submitted to initial surgical treatment and $68 \%$ received conservative treatment. Seven $(29 \%)$ underwent surgery subsequently. In the surgical group, there were seven cases of odontoid type II fractures, two cases of fracture of posterior elements of the axis, one case of C1-C2 dislocation with associated fractured $\mathrm{C} 2$, one case of occipitocervical dislocation, and one case of combined $\mathrm{C} 1$ and $\mathrm{C} 2$ fractures, and facet dislocation. Only one patient had neurological déficit that improved after treatment. Two surgical complications were seen: a liquoric fistula and one surgical wound infection (reaproached). In the group treated conservatively, odontoid fractures (eight cases) and fractures of the posterior elements of C2 (five cases) were more frequent. In two cases, in addition to the injuries of the craniocervical junction, there were fractures in other segments of the spine. None of the patients who underwent conservative treatment presented neurological deterioration. Conclusion: Although injuries of craniocervical junction are relatively rare, they usually involve fractures of the odontoid and the posterior elements of the axis. Our results recommend early surgical treatment for type II odontoid fractures and ligament injuries, the conservative treatment for other injuries.
\end{abstract}

Keywords: Cervical vertebrae/injuries; Wounds and injuries/classification; Wounds and injuries/surgery; Wounds and injuries/therapy

\section{RESUMO}

Objetivo: Avaliar a correlação entre o tratamento, as características das lesões e o resultado clínico em pacientes com lesões traumáticas na junção craniocervical. Métodos: Estudo retrospectivo de pacientes maiores de 18 anos tratados de forma conservadora ou cirúrgica, entre 2010 e 2013. Resultados: Foram analisados 37 pacientes, 73\% eram do sexo masculino e a média de idade foi de 41,7 anos. Inicialmente $32 \%$ dos pacientes foram submetidos a tratamento cirúrgico, e $68 \%$ foram submetidos a tratamento conservador. Sete pacientes $(29 \%)$ do grupo conservador foram submetidos posteriormente à cirurgia. No grupo cirúrgico, houve sete casos de fratura de odontóide tipo II, dois casos de fratura de elementos posteriores do áxis, um caso de luxação C1-C2, um caso de deslocamento occipito-cervical e um caso de fraturas de $\mathrm{C} 1$ e C2 e luxação facetária. Um paciente apresentava déficit neurológico, melhorando após o tratamento. Houve duas complicações pós-cirúrgicas, uma fístula liquórica e uma infecção de ferida operatória (reabordada). No grupo conservador, predominaram as fraturas do odontóide (oito) e dos elementos posteriores de C2 (cinco). Em dois casos, havia também fraturas em outros segmentos da coluna. Nenhum dos pacientes deste grupo apresentou deterioração neurológica. Conclusão: As lesões da junção craniocervical são raras, sendo mais frequentes as fraturas do odontóide e dos elementos posteriores do áxis. Nossos resultados recomendam o tratamento cirúrgico precoce para os pacientes com fraturas do odontóide tipo II e lesões ligamentares, e tratamento conservador para os demais pacientes.

Descritores: Vértebras cervicais/lesões; Ferimentos e lesões/classificação; Ferimentos e lesões/cirurgia; Ferimentos e lesões/terapia

\footnotetext{
1 Universidade Estadual de Campinas, Campinas, SP, Brazil.

${ }^{2}$ Núcleo do Hospital de Força Aérea de São Paulo, São Paulo, SP, Brazil.

Corresponding author: Luiz Adriano Esteves - Núcleo do Hospital de Força Aérea de São Paulo - Divisão de Neurologia - Avenida Olavo Fontoura, 1.400 - Santana - Zip code: 04024-002 - São Paulo, SP, Brazil - Phone: (55 11) 2224-7106 - E-mail: luizadriano@einstein.br

Received on: May 21, 2015 - Accepted on: Oct 20, 2016

Conflict of interest: none.

DOI: 10.1590/\$1679-45082016A03396
} 


\section{INTRODUCTION}

Traumatic injuries of the craniocervical junction (CCJ) affect mostly young adults, and cause enormous physical, psychological and social consequences. While the frequency of spinal injuries is increasing due to the growing number of traffic accidents, the mortality has fallen mainly due to the improvement of the initial treatment. ${ }^{(1-3)}$

Traumatic injuries of the CCJ characteristically involve the skull base, the atlas and axis. ${ }^{(3)}$ They have a low prevalence compared with injuries of other spinal segments and they present unique characteristics, such as the complex ligamentous structure responsible to maintain stability on the region. ${ }^{(2)}$

The treatment of these lesions aims to prevent further neurological injury and restore spinal stability. ${ }^{(2,4,5)}$ Especifically dealing with traumatic injuries of the CCJ, multiple fractionated classification systems were proposed to guide treatment, such as those by Anderson et al., for odontoid process fractures, ${ }^{(6)}$ by Effendi et al., for fractures of the posterior elements of the axis arch, ${ }^{(7)}$ and by Traynelis et al., for occipital atlantoaxial dislocation. ${ }^{(8)}$ Some of the classic systems were proposed prior to the advent of modern computed tomography (CT) and magnetic resonance imaging (MRI), which may have precluded a more detailed morphological characterization of osseous and neural tissues compared with these new radiological methods. More importantly, the lack of more clear and comprehensive guidelines contributes to hamper the decision making process between conservative versus surgical treatments.

\section{OBJECTIVE}

To evaluate the correlation between the treatment, the characteristics of the lesions and the clinical outcome of patients with traumatic injuries to the craniocervical junction.

\section{METHODS}

A retrospective case series was performed including patients with CCJ spinal trauma treated from 2010 to 2013 at the Hospital of the Universidade de Campinas, Campinas (SP) Brazil. We have excluded patients younger than 18 years old, those who had incomplete medical charts and those with pathological fractures.

The clinical and radiological data were evaluated to classify traumas according to patients' neurological status, injuries morphology and treatment (conservative versus surgical treatment). Treatment was performed according to our institution's algorithm (Figure 1). Ligamentous injuries were referred to early surgical

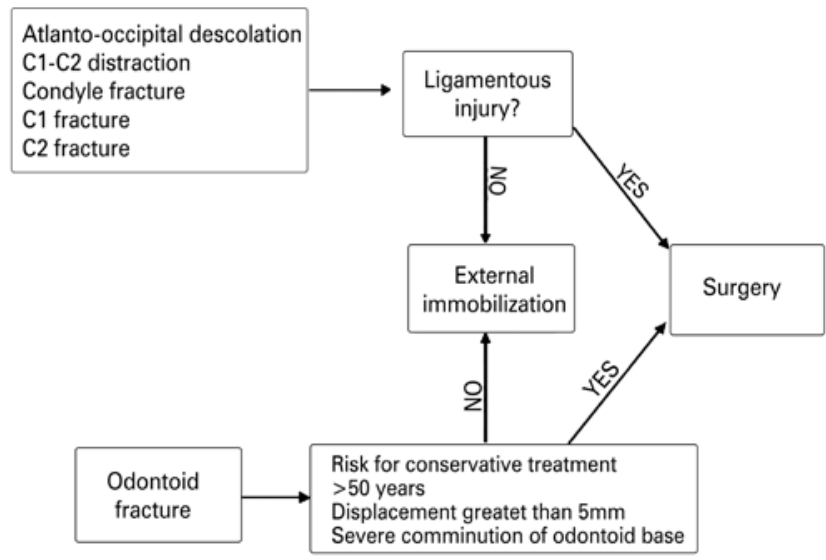

Source: Joaquim et al.!10)

Figure 1. Treatment decision flowchart of patients with lesions in the craniocervical junction (suggested treatment)

fixation whereas bone fractures without ligamentous injuries were treated according to each injury characteristic (only fracture in the dens base with risk factors for non union were referred for early surgical treatment). Patients were followed after surgery in the outpatient clinic with postoperative CT scan and plain radiographies.

Epidemiological data were presented in a descriptive statistical form and compared with the literature. The specific data were analyzed using the IBM Statistical Package for Social Sciences (SPSS) version 21 for Windows ${ }^{\circledR}$.

The analysis of the groups in relation to the categorical variables used Fisher's exact test. To compare groups in relation to the numerical variables we used non-parametric Mann-Whitney test. The significance level considered was $\mathrm{p} \leq 0.05$.

The study was approved by the Research Ethics Committee of the Faculdade de Ciências Médica da Universidade Estadual de Campinas number 574.524, CAAE: 24566614.4.0000.5404. A Consent Form was not required.

\section{RESULTS}

We included 43 patients with spinal trauma in the CCJ. Of these, six were excluded: two because of insufficient medical records, one for early death (severe head injury) before any treatment, and three because of being younger than 18 years. Finally, 37 patients were analyzed.

Of the patients, 27 (72.9\%) were men. Patients' age ranged from 20 to 93 years (mean 41.70, standard deviation of $37 \pm 16.72$ years). 
Traffic accidents were the main cause of spinal trauma $(59.46 \%)$, followed by falls $(27.03 \%)$.

Initially, 24 patients $(64.9 \%)$ underwent conservative treatment with rigid cervical collar (Philadelphia), and 12 patients $(32.4 \%)$ underwent surgical treatment. One patient $(2.7 \%)$ preseted with severe traumatic brain injury and was referred to later treatment at our institution, with C1-C2 dislocation that was undiagnosed at the service of origin. Patients underwent early surgical treatment when they were at risk for non-consolidation of the fracture, as shown in the algorithm exposed in figure 1.

In the follow-up, seven patients were initially treated conservativelly (29.2\%) and underwent late surgery due to treatment failure (non healing in postoperative CT scan after 12 weeks and pain at the fracture site). Among those, six patients presented odontoid fracture in the dens base (all without risk factors for non-union) and one had a non-healed fracture in the posterior elements of the axis. None of these seven patients had delayed neurological déficits. All these patients were treated initially with a rigid cervical collar (Philadelphia) and surgery was a posterior C1-2 fixation using screws.

\section{Initial conservative treatment}

Among 24 patients who initially underwent conservative treatment (Table 1 and Figure 2), five were women $(20.8 \%)$ and 19 were men $(79.1 \%)$. Patients' age ranged from 21 to 93 years old (mean 42.5 years, standard deviation of \pm 17.25 ).

Table 1. Classification of the patients who received initial conservative treatment

\begin{tabular}{lc}
\hline Injury description & $\mathbf{n}(\%)$ \\
\hline Odontoid fracture & \\
Type II (low risk non-consolidation) & $7(29.2)$ \\
Tipe III & $1(4.2)$ \\
Hangman fracture & \\
Type I & $2(8.3)$ \\
Type II & $3(12.5)$ \\
Occipital condyle fracture & \\
Type I & $2(8.3)$ \\
Type II & $2(8.3)$ \\
C1 lateral mass fracture & $1(4.2)$ \\
C1 posterior arch fracture & $1(4.2)$ \\
C2 body fracture & $2(8.3)$ \\
Multiple fractures & \\
Hangman type I + C1 posterior arch & $3(12.5)$ \\
Condyle type I + C2 top facet & \\
C1 anterior arch + C2 body & \\
\hline
\end{tabular}
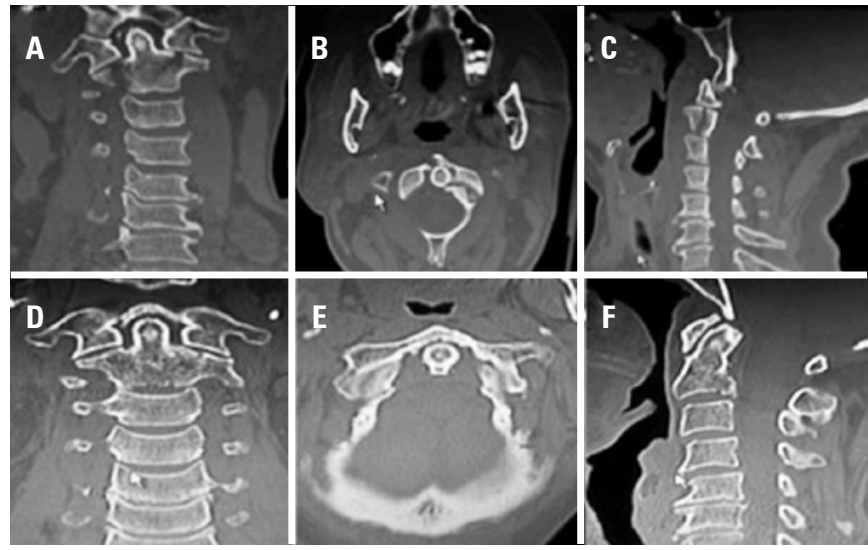

Figure 2. Combined anterior arch of $\mathrm{C} 1$ and $\mathrm{C} 2$ body fractures - conservative treatment. Line 1: computed tomography images showing the fractures before treatment. (A) coronal, (B) axial, (C) sagittal sections. Line 2: fractures are consolidated after eight weeks of conservative treatment. (D) coronal, (E) axial and (F) sagittal sections

Fractures in a single vertebra were found in 21 patients $(87.5 \%)$. Three patients had multiple fractures in the spine $(12.5 \%)$. Among those, one patient (4.2\%) had fractures in $\mathrm{C} 1$ and $\mathrm{C} 2$. Two patientes $(8.3 \%)$ presented damage in other segments of the spine, in addition to the injuries of the CCJ (T3-T4 and L12).

None of these patients had neurological déficits due to the injury of the CCJ. One patient had neurological déficits due to spinal cord injury caused by trauma to the thoracic spine (T3-T4). There were no deaths during follow-up nor delayed neurological deterioration. All patients were followed for a minimum period of 8 weeks.

\section{Failure to initial conservative treatment}

Among patients who initially underwent conservative treatment, seven underwent surgery subsequently due to treatment failure. Among these patients, five were men $(71.4 \%)$. The age distribution was 23 to 64 years, mean 36.5 years, and standard deviation of \pm 12.95 . None of the patients had neurological déficits.

In our series of seven patients with type II odontoid fractures initially treated conservatively, six underwent surgery subsequently due to non-healing of the fracture. Although conservative treatment was accepted for patients without risk factors for non-consolidation, we noticed that adequate consolidation did not occur in $83 \%$ our cases (Figure 3). The high failure rate of conservative treatment for fractures of odontoid type II led us to correlate no healing of the fracture with conservative treatment $(\mathrm{p}=0.001)$ (Tables 2 to 4$)$. 

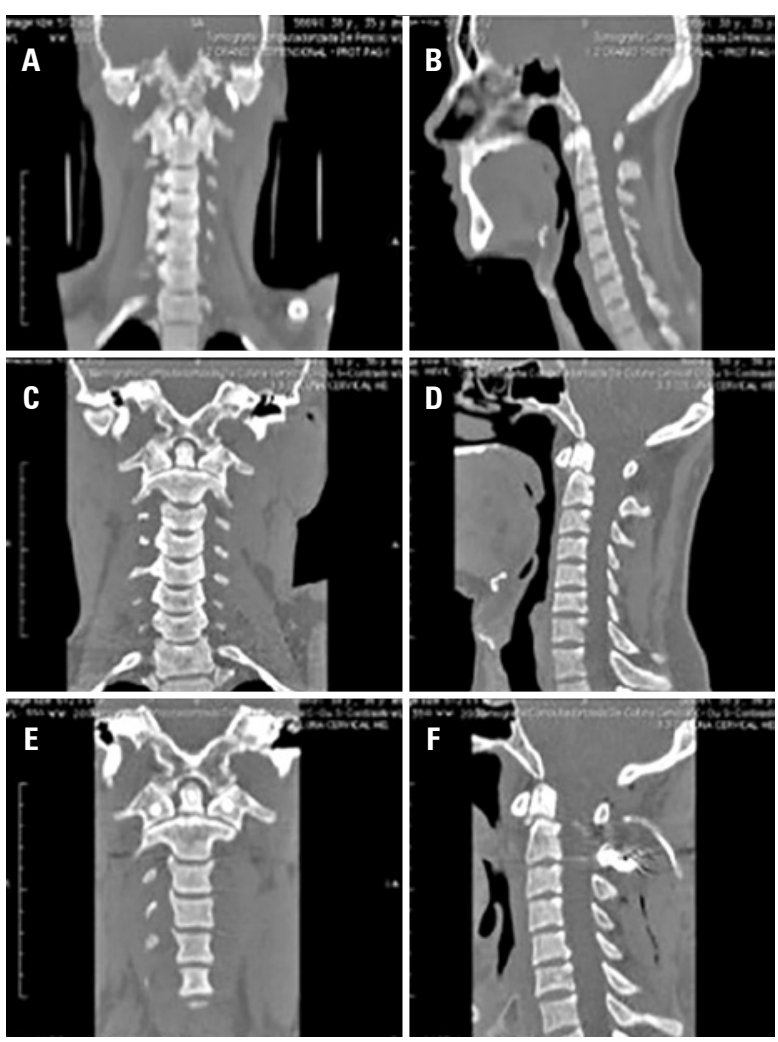

Figure 3. Odontoid fracture type II, conservative treatment failure. (A and $B$ ) non-comminuted odontoid fracture without deviation in a 37 years old patient, ( $C$ and $D$ ) computed tomography scan after eight weeks of conservative treatment showing, (E and F) surgical result after posterior C1-C2 arthrodesis

Table 2. Fractures in patients with conservative treatment failure

\begin{tabular}{lccc}
\hline Lesion & Total number & Non-healed & $\mathbf{( \% )}$ \\
\hline Odontoid fracture type II & 7 & 6 & $25^{*}$ \\
Hangman fracture type II & 3 & 1 & $4.2^{\dagger}$ \\
Other injuries & 14 & 0 & 0 \\
\hline${ }^{*}$ 85.7\% of patients with odontoid fracture type II treated conservatively: ${ }^{\dagger} 33.3 \%$ of patients with hangman fracture \\
type II treated conservatively.
\end{tabular}

Table 3. Risk factors according to the treatment performed

\begin{tabular}{|c|c|c|c|c|c|}
\hline \multirow[b]{2}{*}{$\begin{array}{l}\text { Number of risk } \\
\text { factors }\end{array}$} & \multicolumn{3}{|c|}{ Therapeutic procedures } & \multirow[b]{2}{*}{ Total } & \multirow[b]{2}{*}{ p value ${ }^{*}$} \\
\hline & $\begin{array}{l}\text { Early } \\
\text { surgery }\end{array}$ & Conservative & $\begin{array}{l}\text { Surgery after } \\
\text { conservative } \\
\text { failure }\end{array}$ & & \\
\hline None & 0 & $1(100)$ & $6(100)$ & $7(50)$ & $0.001^{\dagger}$ \\
\hline One & $5(71)$ & 0 & 0 & $5(36)$ & \\
\hline Two & $2(29)$ & 0 & 0 & $2(14)$ & \\
\hline
\end{tabular}

"Fischer exact test; ${ }^{\dagger} p<0.01$.

Table 4. Computed tomography versus treatment group to odontoid fracture type II

\begin{tabular}{lcccc}
\hline \multirow{2}{*}{ Results } & \multicolumn{2}{c}{ Groups } & \multirow{2}{*}{ Total } & \multirow{2}{*}{ p value } \\
\cline { 2 - 4 } & Early surgery & Conservative & & \\
\hline Success & $7(100)$ & $1(14)$ & $8(57)$ & 0.005 \\
Non-consolidation & 0 & $5(71)$ & $5(36)$ & \\
$\begin{array}{l}\text { Non-consolidation and } \\
\text { deviation }\end{array}$ & 0 & $1(14)$ & $1(7)$ & \\
\hline Total & $7(100)$ & $7(100)$ & $14(100)$ & \\
\hline Fischer exact test; $p<0.01$. & & & &
\end{tabular}

\section{Patients undergoing initial surgical treatment}

Two patients had complications (16.6\%). One case of fistula treated during surgery, and one case of surgical site infection, which required surgical debridement and antibiotic therapy.

Among the 12 patients initially treated with surgery, only 1 presented pre-operative neurological déficits (improving from ASIA C to D during follow-up). There were no instances of new neurological symptoms or death.

All patients were followed for a minimum period of 8 weeks to a maximum of 6 months.

\section{DISCUSSION}

The most frequently found injury in our series was the odontoid fracture, affecting 15 patients (40.54\%). Among those, 14 patients had their fracture classified according to Anderson et al., as type II (involving the base of the odontoid process) and one as type III (involving the axis body). ${ }^{(6)}$ Seven cases received indication of early surgical treatment, due to the presence of factors associated with high risk of non-union. ${ }^{(9,10)}$ The remaining patients were treated with immobilization using a Philadelphia collar.

Regarding the treatment of odontoid fractures, Clark et al., ${ }^{(11)}$ reported the immobilization treatment of types II and III fractures as essential to achieve consolidation. However, consolidation rates in type II fractures with conservative treatment are around $43 \%$, different than type III fractures, in which consolidation is observed in almost $87 \%$ of cases. ${ }^{(11)}$

Traynelis et al.,(12) in the largest published study of axis fractures, including 340 cases (199 odontoid fractures) treated with halo vest, obtained $100 \%$ healing in type I fractures and $82 \%$ in type III. In type II fractures, non-surgical treatment failed in $28 \%$ of cases with up to $84 \%$ in the case of displacement of the fractured fragment larger than $6 \mathrm{~mm}$. They suggested that patients with fracture displacement greater than $6 \mathrm{~mm}$ should undergo early surgical treatment.

In patients with surgical indication, posterior instrumentation has shown a high rate of arthrodesis. ${ }^{(13-15)}$ In the literature review produced by Julien et al., ${ }^{(13)}$ 147 patients were retrospectively analyzed with types II and III fractures, obtaining $87 \%$ of healing in type II and $100 \%$ in type III fractures treated with posterior fixation.

Alternatively, for patients with good bone quality and low risk of postoperative dysphagia, fixation by an anterior approach using an odontoid screw is a reasonable option, with consolidation rates of up to 
$89 \%$ to $100 \%$. This technique has the advantage of preserving mobility between the atlanto-axial joint but it is contraindicated in chronic fractures. ${ }^{(9,10)}$

Finally, in elderly patients, with more than 60 years, several authors ${ }^{(13,16)}$ suggest that the consolidation of fractures with external immobilization is not a good treatment option, since the consolidation rates are generally less than $30 \%$. Controversily, our patients who had failure conservative treatment had a lower mean age (36.5 years) compared with the whole group treated conservatively (42.5 years).

Regarding the use of immobilization by Philadelphia colar or halo vest, Lewis et al., ${ }^{(17)}$ evaluated 67 patients with odontoid fractures, 32 treated with Philadelphia collar and 37 with halo vest. Consolidation after 3 months was $60 \%$ for the group with halo vest versus $35 \%$ for the group with cervical collar. There were more clinical complications on patients treated with halo vest $-60 \%$ versus $6 \%$ for the group using Philadelphia colar. Despite the differences in bone healing, there was no statistical difference, allowing them to conclude that there was no superiority of one immobilization compared to the other. ${ }^{(18)}$

Despite the high failure rate of conservative treatment, due to its relative low morbidity, it is still a treatment option, once the patient is informed about the likelihood of needing a late surgical procedure and the importance of close clinical and radiological follow-up. After analyzing our results, we are now offering surgery for type 2 odontoid fractures even without risk factors for non-union, explaining the risks and benefits of conservative or surgical treatment. Although we currently advocate surgical fixation, patients should also be consulted in relation to their opinion about the treatment offered.

\section{Fracture of the posterior elements of the axis}

The second most prevalent injury in our series was traumatic spondylolisthesis of the axis, also known as lesions of the posterior elements of the axis or Hangman fracture. There were nine cases $(24.32 \%)$ in our series.

The treatment of the posterior elements of the axis fracture is relatively well established. ${ }^{(19,20)}$ It is primarily non-surgical, preferably treated with the use of a rigid cervical collar, with surgery reserved for non-healing or deformity or classified fractures as Levine type III. This latter had C2-C3 facet dislocation and ligamentous injuries, which is treated preferentially by surgery in the majority of series already published. ${ }^{(20,21)}$ Anterior or posterior $\mathrm{C} 2-\mathrm{C} 3$ fixation can be used according to surgeon's preference and injury characteristics..$^{(9,19,20)}$

\section{Occipital condyle fractures}

The occipital condyle fractures were diagnosed in six patients $(16.22 \%)$. The condylar fracture is probably underdiagnosed because the clinical presentation is variable and it presents no specific signs on physical examination. They are associated with severe head trauma. ${ }^{(21,22)}$

Saternus ${ }^{(22)}$ in a study involving all victims of accidents with injury mechanisms compatible with condyle fracture, found an incidence of $16 \%$ of fractures. Literature review conducted by the American Association of Neurological Surgeons ${ }^{(22,23)}$ concluded that not treating condylar fractures is unacceptable. This review identified 23 patients who did not receive treatment: 9 of them had no neurological déficits during follow-up. Six other developed late déficits, as well as vertigo and nystagmus. In general, with the exception of bilateral fractures associated with atlantooccipital displacement, the condyle fractures can be successfully treated with a rigid cervical collar. ${ }^{(10,22-24)}$

In our series, one patient had bilateral condyle fractures associated with occipital-C1 and $\mathrm{C} 1-\mathrm{C} 2$ dislocation, who underwent an occipital-C2-C3 fixation. There was also a case of condyle fracture associated with lateral mass fracture of $\mathrm{C} 1$, which like the other four cases of unilateral fracture of the condyle, underwent conservative treatment with a rigid cervical collar. None of the patients had neurological déficits nor worsened during the follow-up.

\section{Atlas and axis fractures without ligamentous injuries}

The atlas fractures occur alone or associated with other fractures. They account for about 1 to $2 \%$ of the spinal fractures and 13 to $22 \%$ of cervical spine fractures. ${ }^{(21,23,25)}$ These fractures can compromise the anterior, the posterior arch, the lateral mass and the transverse process and may be associated with ligamentous injuries. Thakar et al., ${ }^{(26)}$ in a prospective series of $\mathrm{C} 1$ fractures treated with Philadelfia collar and halo vest, obtained $94 \%$ of good results without the need for surgical intervention.

The axis body fractures (no-Hangman) formed a small group. Hadley et al., ${ }^{(23)}$ reported excellent results with conservative treatment, as surgery should be reserved for cases of burst fracture type or that have other associated injuries.

In our series, there was one case of $\mathrm{C} 1$ fracture with facet dislocation treated surgically. The other lesions were successfully treated conservatively with immobilization with a cervical collar. No patient had neurological déficits or worsened during follow-up. 
Of note, our study is limited by its retrospective nature and because we did not access other confounds factors that may affect bone healing, such as smoking. Additionally, the small number of patients requires caution when interpretating the statisctical analysis.

\section{CONCLUSION}

In our series of traumatic craniocervical junction injuries, odontoid fractures and fractures of the posterior elements of the axis were the most prevalent injuries.

Patients with ligamentous injury were treated successfully with surgery whereas those with isolated bone fractures were preferentially treated with a rigid cervical collar. Our results suggest that early surgery in type II odontoid fractures should be considered due to the high rate of non-consolidation even when factors associated with higher risk for non-union are absent.

\section{REFERENCES}

1. Kraus JF. Epidemiologic features of head and spinal cord injury. Adv Neurol. 1978;19:261-79. Review.

2. Menezes AH, Traynelis VC. Anatomy and biomechanics of normal craniovertebral junction (a) and biomechanics of stabilization (b). Childs Nerv Syst. 2008;24(10): 1091-100. Review.

3. Sances A Jr, Myklebust JB, Maiman DJ, Larson SJ, Cusick JF, Jodat RW. The biomechanics of spinal injuries. Crit Rev Biomed Eng. 1984;11(1):1-76. Review.

4. Botelho RV, Borgheresi MD, Batista AL. Trauma raquimedular craniocervical: Revisão de literatura. Arq Bras Neuro. 2008;27(4):122-35.

5. Hadley MN, Walters BC, Grabb PA, Oyesiku NM, Przybylski GJ, Resnick DK, et al. Guidelines for the management of acute cervical spine and spinal cord injuries. Clin Neurosurg. 2002;49:407-98. Review.

6. Anderson LD, D'Alonzo RT. Fractures of the odontoid process of the axis. $J$ Bone Joint Surg Am. 1974;56(8):1663-74.

7. Effendi B, Roy D, Cornish B, Dussault RG, Laurin CA. Fractures of the ring of the axis. A classification based on the analysis of 131 cases. J Bone Joint Surg Br. 1981;63-B(3):319-27.

8. Traynelis VC, Marano GD, Dunker RO, Kaufman HH. Traumatic atlanto-occipital dislocation Case report. J Neurosurg. 1986;65(6):863-70. Erratum in: J Neurosurg. 1987;66(5):789.

9. Joaquim AF, Patel AP. Occipito cervical trauma: evaluation, classification and treatment. Contemp Spine Surg. 2010;11(4):1-5.
10. Joaquim AF, Ghizoni E, Tedeschi H, Yacoub AR, Brodke DS, Vaccaro AR, et al. Upper cervical injuries: clinical results using a new treatment algorithm. J Craniovertebr Junction Spine. 2015;6(1):16-20.

11. Clark CR, White AA 3rd. Fractures of the dens. A multicenter study. J Bone Joint Surg Am. 1985;67(9):1340-8.

12. Traynelis V. Evidence-based management of type II odontoid fractures. Clin Neurosurg. 1997:44:41-9. Review.

13. Julien TD, Frankel B, Traynelis VC, Ryken TC. Evidence-based analysis of odontoid fracture management. Neurosurg Focus. 2000;8(6):e1. Review.

14. Campanelli M, Kattner KA, Stroink A, Gupta K, West S. Posterior C1-C2 transarticular screw fixation in the treatment of displaced type II odontoid fractures in the geriatric population--review of seven cases. Surg Neurol. 1999;51(6):596-600; discussion 600-1.

15. Dai LY, Yuan W, Ni B, Liu HK, Jia LS, Zhao DL, et al. Surgical treatment of nonunited fractures of the odontoid process, with special reference to occiptocervical fusion for unreductible atlantoaxial subluxation or instability. Eur Spine J. 2000;9(2):118-22.

16. Pitzen T, Caspar W, Steudel WI, Barbier D. [Dens fracture in elderly patients and surgical management]. Aktuelle Traumatol. 1994;24(2):56-9. German.

17. Lewis $E$, Liew $S$, Dowrick $A$. Risk factors for non-union in the non-operative management of type II dens fractures. ANZ J Surg. 2011;81(9):604-7.

18. van Middendorp JJ, Sloof WB, Nellestein WR, Oner FC. Incidence of and risk factors for complications associated with halo-vest immobilization: a prospective, descriptive cohort study of 239 patients. J Bone Joint Surg Am. 2009;91(1):71-9.

19. Li XF, Dai LY, Lu H, Chen XD. A systematic review of the management of hangman's fractures. Eur Spine J. 2006;15(3):257-69. Review.

20. Moon MS, Moon JL, Moon YW, Sun DH, Choi WT. Traumatic spondylolisthesis of the axis: 42 cases. Bull Hoap Jt Dis. 2001-2002;60(2):61-6.

21. Hammer AJ. Lower cranial nerve palsies. Potentially lethal in association with upper cervical fracture-dislocations. Clin Orthop Relat Res. 1991;(266):64-9.

22. Saternus KS. [Forms of fractures of the occipital condyles]. Z Rechtsmed 1987;99(2):95-108. German.

23. Hadley MN, Dickman CA, Browner CM, Sonntag VK. Acute traumatic atlas fractures: management and long term outcome. Neurosurgery. 1988;23(1): 31-5.

24. Harris JH Jr, Carson GC, Wagner LK, Kerr N. Radiologic diagnosis of traumatic occipitovertebral dissociation: 2. Comparison of three methods of detecting occipitovertebral relationships on lateral radiographs of supine subjects. AJR Am J Roentgenol. 1994;162(4):887-92.

25. Hanigan WC, Powell FC, Elwood PW, Henderson JP. Odontoid fractures in elderly patients. J Neurosurg. 1993;78(1):32-5.

26. Thakar C, Harish S, Saifuddin A, Allibone J. Displaced fracture through the anterior atlantal synchondrosis. Skeletal Radiol. 2005;34(9):547-9. 